\begin{tabular}{|c|c|c|}
\hline \multirow{2}{*}{$\begin{array}{r}\text { Case Reports in } \\
\text { Gastroenterology }\end{array}$} & \multicolumn{2}{|c|}{ Case Rep Gastroenterol 2019;13:450-455 } \\
\hline & $\begin{array}{l}\text { DOl: } 10.1159 / 000503895 \\
\text { Published online: October 30, } 2019\end{array}$ & $\begin{array}{l}\text { ( } 2019 \text { The Author(s) } \\
\text { Published by S. Karger AG, Basel } \\
\text { www.karger.com/crg }\end{array}$ \\
\hline & $\begin{array}{l}\text { This article is licensed under the } \\
\text { International License (CC BY-NC) } \\
\text { Usage and distribution for commerc }\end{array}$ & $\begin{array}{l}\text { mons Attribution-NonCommercial } 4.0 \\
\text { ger.com/Services/OpenAccessLicense). } \\
\text { guires written permission. }\end{array}$ \\
\hline
\end{tabular}

\title{
Pancreatic Pseudoaneurysm from a Gastroduodenal Artery
}

\author{
Dhineshreddy Gurala ${ }^{a} \quad$ Abhishek Datta Polavarapu ${ }^{b}$ Pretty Sara Idiculla ${ }^{c}$ \\ Magda Daoud ${ }^{\mathrm{b}} \quad$ Vivek Gumaste $^{\mathrm{b}}$ \\ anternal Medicine, Staten Island University Hospital, Northwell Health, Staten \\ Island, NY, USA; ${ }^{b}$ Gastroenterology and Hepatology, Staten Island University Hospital, \\ Northwell Health, Staten Island, NY, USA; 'Medicine, Sree Gokulam Medical College and \\ Research Foundation, Trivandrum, India
}

\section{Keywords}

Abdominal pain · Pancreas · Pseudoaneurysm

\begin{abstract}
Pancreatic pseudoaneurysm is a rare vascular complication of pancreatitis, resulting from erosion of the pancreatic or peripancreatic artery into a pseudocyst. However, it may happen after pancreatic or gastric bypass surgery or trauma. It may lead to fatal complications if left untreated. Herein, we report a unique case of pseudoaneurysm from a gastroduodenal artery in a patient with recurrent episodes of acute pancreatitis, which was managed successfully with coil embolization.

(c) 2019 The Author(s)

Published by S. Karger AG, Basel
\end{abstract}

\section{Introduction}

Pancreatic pseudoaneurysm is an uncommon clinical entity, created due to the erosion of the pancreatic or peripancreatic artery into a pseudocyst. Pseudoaneurysm differs from a true aneurysm in terms of the wall of the pseudoaneurysm being composed of fibrous tissue instead of an arterial wall as in the true aneurysm. It is a rare vascular complication after pancreatitis with an estimated prevalence of less than 10\% [1]. Splenic artery involvement is more common in up to $50 \%$ of cases followed by the gastroduodenal, pancreaticoduodenal, 


\section{Case Reports in Gastroenterology}

Case Rep Gastroenterol 2019;13:450-455 DOI: 10.1159/000503895

(c) 2019 The Author(s). Published by S. Karger AG, Basel www.karger.com/crg

Gurala et al.: Pancreatic Pseudoaneurysm from a Gastroduodenal Artery

superior mesenteric, left gastric, and hepatic artery. Common presenting symptoms may vary from bleeding secondary to rupture or abdominal pain, or it may be asymptomatic in some patients. These aneurysms are frequently accompanied by life-threatening complications, mainly rupture and bleeding. Bleeding can occur in the pseudocyst itself, via the ampulla of Vater, or by fistulation into nearby hollow organs. Due to their instability and subsequent risk of massive bleeding, prompt treatment is necessary. Endovascular embolization and surgery are the primary modalities of treatment.

\section{Case Presentation}

A 30-year-old male with a history of alcohol abuse for the last 2 years (4 drinks/day), recurrent alcoholic pancreatitis (last episode 3 weeks ago), and splenic vein thrombosis on Xarelto presented to the emergency department with 4 days of abdominal pain. Pain was in the epigastric region, dull in nature, 7/10 in intensity, radiating to the back, associated with nausea but with no relation to food intake or bowel movement. The patient denied fever, vomiting, hematemesis, melena, or diarrhea. No significant family history of pancreatitis, pancreatic cancer, or other malignancies was present. He was discharged from the hospital 3 weeks ago after an episode of acute interstitial edematous pancreatitis secondary to alcohol intake, which improved with intravenous fluids, pain control, and bowel rest. Physical examination was positive for mild epigastric tenderness without guarding, rigidity, or distension, and bowel sounds were present in all 4 quadrants. Vitals on admission were blood pressure of $130 / 80 \mathrm{~mm} \mathrm{HG}$, heart rate of 90 beats/min, and oxygen saturation of $98 \%$ on room air. Laboratory examination revealed a white blood cell count of 10,000 (normal 4,000-10,000), hemoglobin of $12.6 \mathrm{~g} / \mathrm{dL}$ (normal 12-15.5 g/dL), hematocrit of 37\% (normal 37-47\%), blood urea nitrogen of $7 \mathrm{mg} / \mathrm{dL}$ (normal $10-20 \mathrm{mg} / \mathrm{dL}$ ), creatinine of $0.5 \mathrm{mg} / \mathrm{dL}$ (normal 0.7-1.5 $\mathrm{mg} / \mathrm{dL}$ ), international normalized ratio of 1.1 (normal $0.65-1.3$ ), triglyceride levels of 140 $\mathrm{mg} / \mathrm{dL}$ (normal 10-149 mg/dL), calcium of $9.4 \mathrm{mg} / \mathrm{dL}$ (normal 8.5-10.1 mg/dL), lipase of 318 $\mathrm{U} / \mathrm{L}$ (normal 7-60 U/L), and lactic acid of $1.9 \mathrm{mmol} / \mathrm{L}$ (normal 0.5-2.2 mmol/L); liver enzymes were within normal limits.

The computed tomography (CT) of the abdomen and pelvis with intravenous contrast showed extensive pancreatic inflammatory changes and fluid collections in the head and proximal body of the pancreas and the new development of a pseudoaneurysm branching from the gastroduodenal artery measuring $2.9 \times 2.1 \times 2.6 \mathrm{~cm}$ (Fig. 1). He was started on intravenous fluids, pain control, and bowel rest. Intervention radiology was consulted for diagnostic angiography and embolization of the pseudoaneurysm under fluoroscopic guidance. Angiography confirmed the results of the CT scan (Fig. 2), and coil embolization of inflow and outflow vessels and of the pseudoaneurysmal sac was performed (Fig. 3). His hemoglobin was stable after the procedure and symptoms were improved. Diet was advanced to a low-fat diet over the subsequent days; Xarelto was resumed. He was discharged from the hospital 3 days after the procedure.

\section{Discussion}

Visceral artery aneurysms are divided into true or pseudoaneurysm [2]. A true aneurysm involves all layers of the vessel wall and is created due to partial digestion of the arterial wall, destroying the elastic tissue of tunica media by the inflammatory process, whereas 


\section{Case Reports in Gastroenterology}

Case Rep Gastroenterol 2019;13:450-455 DOI: 10.1159/000503895

2019 The Author(s). Published by S. Karger AG, Basel www.karger.com/crg

Gurala et al.: Pancreatic Pseudoaneurysm from a Gastroduodenal Artery

pseudoaneurysms are false aneurysms which result from injury to one or more vessel wall layers. Pancreatic pseudoaneurysms are formed by the erosion of the pancreatic or peripancreatic artery into a pseudocyst. They are most common after pancreatitis, but they can also occur after pancreaticobiliary surgery, pancreatic transplantation, trauma, and motor vehicle accident. Pseudoaneurysm was first reported by Starlinger in 1930; since then, there has been an increasing number of reports on gastroduodenal artery aneurysms due to improved radiological techniques. The pathophysiology of these aneurysms is not clearly understood; weakening of the vessel by leakage of proteolytic enzymes has been implicated in the pathogenesis.

Pseudoaneurysms are classified according to the artery they originate from, communication with the gastrointestinal tract, and exposure to pancreatic juice [2]. The most commonly involved artery is the splenic artery (30-50\%) due to its proximity to the pancreas. After the splenic artery, the gastroduodenal artery is involved in $10 \%$ and the pancreaticoduodenal artery in $10 \%$, followed by the superior mesenteric, left gastric, hepatic, and small intrapancreatic arteries $[3,4]$.

Gastroduodenal pseudoaneurysm most commonly presents as gastrointestinal bleeding secondary to rupture (52\%) or as abdominal pain (46\%); it is asymptomatic in $7.5 \%$ and rarely presents as retroperitoneal bleed, intraperitoneal bleed, or bleeding into the pancreatic duct or common bile duct, which can cause obstructive jaundice [5, 6].

In patients presenting with abdominal pain only as in our patient, it is difficult to distinguish pseudoaneurysm from a bout of acute pancreatitis, which usually presents with similar symptoms. CT of the abdomen and pelvis with contrast is often suggestive (sensitivity of $67 \%$ ), but CT angiogram is the gold standard for the diagnosis (sensitivity of 100\%) [7]. Once pseudoaneurysm is diagnosed, it should be treated immediately because of increased mortality up to $90 \%$ in untreated patients and $12.5 \%$ in treated patients. It is recommended to treat even asymptomatic aneurysms given the increase in morbidity and mortality associated with surgery in the setting of rupture.

Treatment modalities include either embolization (coils, covered stent, percutaneous or transcatheter thrombin injection) or surgery [2, 8-11]. Endovascular therapy offers significant advantages in terms of less postoperative pain, shorter hospital stay, and early return to activities of daily life. In the event of failed embolization or rebleeding after embolization surgery, either direct ligation of the bleeding vessel or resection of the pancreas with pseudoaneurysm should be performed [12-14]. Embolization is often the treatment of choice in unstable patients or if the bleeding is still diffuse. Observation after embolization is necessary to monitor for complications, such as early or late re-bleeding, which can occur in $20-40 \%$ of patients [2]. Even though embolization has increased the success rate, there is still an increased risk of recurrence and an overall mortality rate of $16 \%$. Mortality rate after surgery varies from $20-30 \%$.

\section{Conclusion}

Pseudoaneurysm of the gastroduodenal artery is rare. However, it should be considered in the differential diagnosis in patients with chronic pancreatitis, presenting with epigastric pain. Prompt diagnosis and early treatment is mandatory because of potentially life-threatening consequences and increase in mortality if left untreated. 


\section{Statement of Ethics}

Informed consent was obtained from the patient. IRB approval was not needed.

\section{Disclosure Statements}

There are no financial disclosures. The authors declare no conflicts of interest.

\section{Funding Sources}

There are no funding sources.

\section{Author Contributions}

Dr. Gurala and Dr. Polavarapu wrote the introduction, case description, and discussion, Dr. Idiculla drafted the introduction, and Dr. Daoud and Dr. Gumaste reviewed and edited the manuscript.

\section{References}

1 Carr JA, Cho JS, Shepard AD, Nypaver TJ, Reddy DJ. Visceral pseudoaneurysms due to pancreatic pseudocysts: rare but lethal complications of pancreatitis. J Vasc Surg. 2000 Oct;32(4):722-30.

2 Pang TC, Maher R, Gananadha S, Hugh TJ, Samra JS. Peripancreatic pseudoaneurysms: a management-based classification system. Surg Endosc. 2014 Jul;28(7):2027-38.

3 Walter JF, Chuang VP, Bookstein JJ, Reuter SR, Cho KJ, Pulmano CM. Angiography of massive hemorrhage secondary to pancreatic diseases. Radiology. 1977 Aug;124(2):337-42.

4 Pasha SF, Gloviczki P, Stanson AW, Kamath PS. Splanchnic artery aneurysms. Mayo Clin Proc. 2007 Apr;82(4):472-9.

5 Ammori BJ, Madan M, Alexander DJ. Haemorrhagic complications of pancreatitis: presentation, diagnosis and management. Ann R Coll Surg Engl. 1998 Sep;80(5):316-25.

6 Hsu JT, Yeh CN, Hung CF, Chen HM, Hwang TL, Jan YY, et al. Management and outcome of bleeding pseudoaneurysm associated with chronic pancreatitis. BMC Gastroenterol. 2006 Jan;6(1):3.

7 Savastano S, Feltrin GP, Antonio T, Miotto D, Chiesura-Corona M, Castellan L. Arterial complications of pancreatitis: diagnostic and therapeutic role of radiology. Pancreas. 1993 Nov;8(6):687-92.

8 Barbiero G, Battistel M, Susac A, Miotto D. Percutaneous thrombin embolization of a pancreatico-duodenal artery pseudoaneurysm after failing of the endovascular treatment. World J Radiol. 2014 Aug;6(8):629-35.

9 Kukliński A, Batycki K, Matuszewski W, Ostrach A, Kupis Z, Lęgowik T. Embolization of a large, symptomatic splenic artery pseudoaneurysm. Pol J Radiol. 2014 Jul;79:194-8.

10 Barge JU, Lopera JE. Vascular complications of pancreatitis: role of interventional therapy. Korean J Radiol. 2012 Jan-Feb;13 Suppl 1:S45-55.

11 Czernik M, Stefańczyk L, Szubert W, Chrząstek J, Majos M, Grzelak P, et al. Endovascular treatment of pseudoaneurysms in pancreatitis. Wideochir Inne Tech Malo Inwazyjne. 2014 Jun;9(2):138-44.

12 Larrey Ruiz L, Luján Sanchis M, Peño Muñoz L, Barber Hueso C, Cors Ferrando R, Durá Ayet AB, et al. Pseudoaneurysm associated with complicated pancreatic pseudocysts. Rev Esp Enferm Dig. 2016 Sep;108(9):583-5.

13 Venturini M, Marra P, Colombo M, Panzeri M, Gusmini S, Sallemi C, et al. Endovascular Repair of 40 Visceral Artery Aneurysms and Pseudoaneurysms with the Viabahn Stent-Graft: Technical Aspects, Clinical Outcome and Mid-Term Patency. Cardiovasc Intervent Radiol. 2018 Mar;41(3):385-397.

14 Hoshimoto S, Aiura K, Shito M, Kakefuda T, Sugiura H. Successful resolution of a hemorrhagic pancreatic pseudocyst ruptured into the stomach complicating obstructive pancreatitis due to pancreatic cancer: a case report. World J Surg Oncol. 2016 Feb;14(1):46. 


\section{Case Reports in Gastroenterology

\begin{tabular}{l|l}
\hline Case Rep Gastroenterol 2019;13:450-455 \\
\hline DOI: 10.1159/000503895 & $\begin{array}{l}\text { @ 2019 The Author(s). Published by S. Karger AG, Basel } \\
\text { www.karger.com/crg }\end{array}$ \\
\hline
\end{tabular} \\ Gurala et al.: Pancreatic Pseudoaneurysm from a Gastroduodenal Artery}

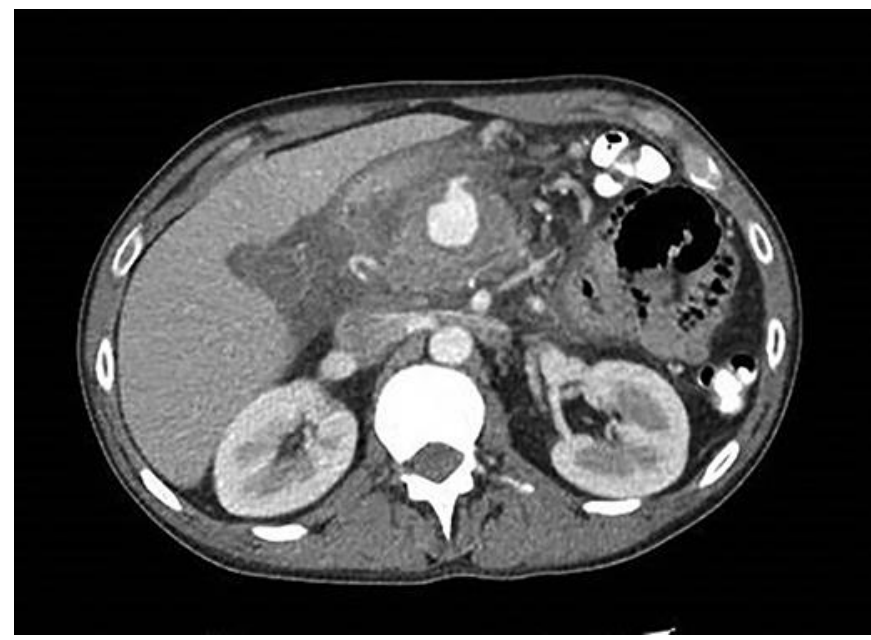

Fig. 1. Development of a pseudoaneurysm branching from the gastroduodenal artery.

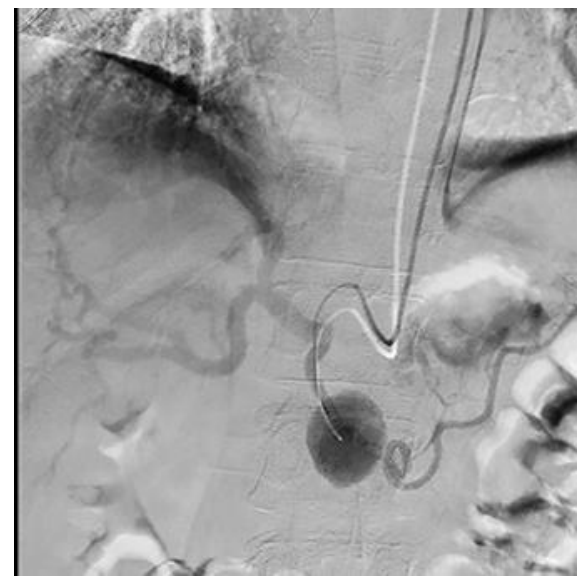

Fig. 2. Angiography showing uptake of contrast by the pseudoaneurysm from the gastroduodenal artery. 


\begin{tabular}{|c|c|c|}
\hline \multirow{2}{*}{$\begin{array}{l}\text { Case Reports in } \\
\text { Gastroenterology }\end{array}$} & \multicolumn{2}{|c|}{ Case Rep Gastroenterol 2019;13:450-455 } \\
\hline & DOI: $10.1159 / 000503895$ & $\begin{array}{l}\text { () } 2019 \text { The Author(s). Published by S. Karger AG, Basel } \\
\text { www.karger.com/crg }\end{array}$ \\
\hline
\end{tabular}

Gurala et al.: Pancreatic Pseudoaneurysm from a Gastroduodenal Artery

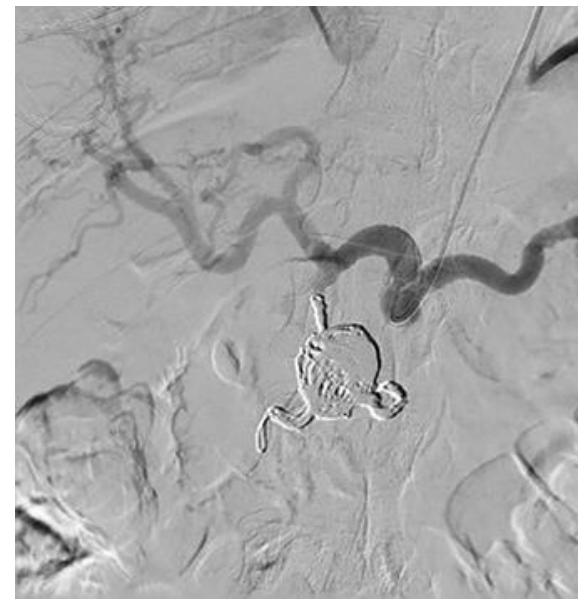

Fig. 3. No contrast in the pseudoaneurysm after successful coil embolization of the pseudoaneurysm. 